\title{
Analysis on Talent Training Models in Foreign Business Schools
}

\author{
Fang ZHAO \\ Business School \\ University of Jinan \\ Jinan, China \\ e-mail: se_zhaof@ujn.edu.cn
}

\author{
Xiangkai ZOU \\ Business School \\ University of Jinan \\ Jinan, China \\ e-mail: zouxiangkai@hotmail.com
}

\begin{abstract}
Today, there is an increasing demand for business talents in China. Thus, it is extremely favorable for Chinese business schools to learn from overseas famous business schools. We carried out questionnaire survey and spot investigation on universities both in China and many developed countries such as Great Britain, Germany, America, Japan, etc. Based on the results, this paper analyzes talent training models in detail among foreign business schools in terms of educational objective, curriculum, teaching methods and cultivation system. The results indicate that the development level of talent education in overseas business schools is relatively high, which is presented in teaching's close integration with enterprises, large scale of education, and close international exchanges.
\end{abstract}

Keywords-talent training models; foreign business schools; teaching methods; cultivation system

\section{INTRODUCTION}

It is reported by various forms of social surveys that there has been a growing demand for business talents in China in recent years. Meanwhile, Chinese business schools still have certain defects both in course selection and teaching training model with only over 20 years of development in comparison with foreign business schools that have formed a relatively perfect system with the development of more than 100 years. Therefore, it is favorable for Chinese business schools to analyze the current situation of higher education and learn from experiences of several major famous business schools. For this reason, we conducted field research and questionnaire survey on many famous business schools, including those in America, Japan, Germany, Canada, Britain, Australia, New Zealand, etc. This paper analyzes different talent training models in some famous overseas business schools in the following four aspects: educational objective, curriculum, teaching methods and cultivation system.

\section{EducAtional ObJective}

Educational objective, designed by universities, is the soul of specialty cultivation plan, and is the orientation towards talent training. In addition, it takes social demand for talents into account and is formulated under the guidance of certain principles of talents training. Table 1 lists talents educational objectives of several overseas famous business schools, which aim to cultivate talents at different levels.

TABLE I. TALENTS EdUCATIONAL OBJECTIVES OF OVERSEAS FAMOUS BusinesS SCHOOLS

\begin{tabular}{|c|c|c|c|}
\hline \multirow{2}{*}{ Business Schools } & \multicolumn{3}{|c|}{ Classification of Education Level } \\
\hline & Undergraduate & $M B A$ & Ph.D. \\
\hline Harvard Business School & $\begin{array}{l}\text { Let students understand world } \\
\text { economy and business operations, } \\
\text { and cultivate top managers. }\end{array}$ & 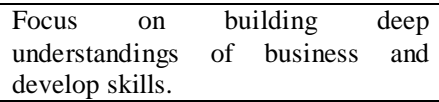 & $\begin{array}{l}\text { Cultivate outstanding scholars } \\
\text { engaged in teaching and research. }\end{array}$ \\
\hline $\begin{array}{l}\text { Wharton School of the } \\
\text { University of Pennsylvania }\end{array}$ & $\begin{array}{l}\text { Provide the basis for leadership and } \\
\text { provide students with knowledge that } \\
\text { can combine business and freedom. }\end{array}$ & $\begin{array}{l}\text { Develop the most effective managers } \\
\text { who can adjust to the global business } \\
\text { environment. }\end{array}$ & $\begin{array}{l}\text { Provide students with cross boundary } \\
\text { research tools to integrate students' } \\
\text { interests and career requirements } \\
\text { with the most advanced business } \\
\text { concepts. }\end{array}$ \\
\hline $\begin{array}{l}\text { Stanford Graduate School of } \\
\text { Business }\end{array}$ & $\begin{array}{l}\text { Provide opportunities for students to } \\
\text { discover new information under the } \\
\text { guidance of excellent teachers. }\end{array}$ & $\begin{array}{l}\text { Train leaders and create ideas that } \\
\text { can change the world. }\end{array}$ & $\begin{array}{l}\text { Train talents engaged in management } \\
\text { academic research and management } \\
\text { teaching. }\end{array}$ \\
\hline London Business School & $\begin{array}{l}\text { Focus on basic skills, such as } \\
\text { finance, accounting, marketing, etc., } \\
\text { especially independent thinking } \\
\text { skills. }\end{array}$ & $\begin{array}{l}\text { Develop business skills, knowledge } \\
\text { and confidence, develop strategic } \\
\text { and functional capabilities, and } \\
\text { enhance international awareness }\end{array}$ & Cultivate the best scholars \\
\hline Ivey Business School & $\begin{array}{l}\text { Cultivate competent business people } \\
\text { needed by all regions and industries. }\end{array}$ & $\begin{array}{l}\text { Develop students' skills through case } \\
\text { studies, and career planning }\end{array}$ & $\begin{array}{l}\text { Cultivate individual's ability of } \\
\text { analysis, research and teaching to } \\
\text { provide talents for teaching research. }\end{array}$ \\
\hline
\end{tabular}


In general, there is no unified form among these educational objectives. Some introduce separately while others are involved in major instructions, but all of them are specific and strongly directive which can help students understand employment and design their own learning plans.

TABLE II. CURriculum PlanNING OF Overseas Business SCHOOLS

\begin{tabular}{|c|c|c|c|c|}
\hline $\begin{array}{l}\text { Business } \\
\text { Schools }\end{array}$ & Prerequisite Course & Required Course & Elective Course & Features \\
\hline $\begin{array}{l}\text { Harvard } \\
\text { Business School }\end{array}$ & $\begin{array}{l}\text { Finance \& Accounting } \\
\text { Quantitative Methods } \\
\text { Business Writing } \\
\text { Computer Technology } \\
\text { General Business } \\
\text { Knowledge }\end{array}$ & $\begin{array}{l}\text { Finance } 1 \\
\text { Financial Reporting and Control } \\
\text { Leadership \& Organizational Behavior } \\
\text { Marketing } \\
\text { Technology \& Operations Management } \\
\text { Field Foundations } \\
\text { Strategy } \\
\text { the Entrepreneurial Manager } \\
\text { Finance } 2 \\
\text { Leadership and Corporate Accountability }\end{array}$ & $\begin{array}{l}\text { Students choose from } \\
\text { among } 120 \text { courses in ten } \\
\text { subject areas as well as } \\
\text { field-based learning } \\
\text { opportunities to gain a } \\
\text { more concentrated } \\
\text { expertise in the industries, } \\
\text { functions, and ideas that } \\
\text { interest them most. }\end{array}$ & $\begin{array}{l}\text { 1. Finance and } \\
\text { accounting is the basis } \\
\text { and focus of MBA } \\
\text { curriculum. } \\
2 . \text { It concentrates on } \\
\text { entrepreneurship } \\
\text { management, which has } \\
23 \text { related courses }\end{array}$ \\
\hline $\begin{array}{l}\text { Wharton School } \\
\text { of the University } \\
\text { of Pennsylvania }\end{array}$ & $\begin{array}{l}\text { Financial Accounting } \\
\text { Financial Analysis } \\
\text { Microeconomics } \\
\text { Statistical Analysis on } \\
\text { Management }\end{array}$ & $\begin{array}{l}\text { Financial Accounting } \\
\text { Management Accounting Basis } \\
\text { Financial Analysis } \\
\text { Macroeconomic Analysis and Public } \\
\text { Policy } \\
\text { Government and Business Legal } \\
\text { Environment } \\
\text { Morality and Responsibility } \\
\text { Managerial Economics } \\
\text { Human Management } \\
\text { Team and Leader } \\
\text { Competitive Strategy } \\
\text { Global Strategic Management } \\
\text { Marketing Management } \\
\text { Supply Chain Management } \\
\text { Management Communication }\end{array}$ & $\begin{array}{l}\text { More than } 200 \text { elective } \\
\text { curriculums based on } 19 \\
\text { specialties are provided, } \\
\text { along with double degree } \\
\text { education projects and } \\
\text { personalized education } \\
\text { projects }\end{array}$ & $\begin{array}{l}\text { 1. During the first year, } \\
\text { it pays attention to the } \\
\text { cultivation of reform } \\
\text { spirits, followed by } \\
\text { offering courses of } \\
\text { special areas in the } \\
\text { second year. } \\
2 . \text { Double degree } \\
\text { projects and the } \\
\text { exchange strategies will } \\
\text { help students become the } \\
\text { global business leader } \\
\text { Meanwhile, students' } \\
\text { personalized study } \\
\text { requirements will be } \\
\text { satisfied. }\end{array}$ \\
\hline $\begin{array}{l}\text { Stanford } \\
\text { Graduate School } \\
\text { of Business }\end{array}$ & $\begin{array}{l}\text { Strategic Leadership } \\
\text { Macroeconomics } \\
\text { Microeconomics } \\
\text { Dynamic Competition } \\
\text { Innovatiology }\end{array}$ & $\begin{array}{l}\text { Business Environment Strategy } \\
\text { Marketing Management } \\
\text { Financial Management } \\
\text { Administrative Compensation and } \\
\text { Corporate Control } \\
\text { Business Process Design } \\
\text { Monetary Policy, International Finance } \\
\text { and Circulation Markets }\end{array}$ & $\begin{array}{l}\text { Consumer-oriented } \\
\text { Product Market } \\
\text { Effective Leadership } \\
\text { Management Simulation } \\
\text { Experiment } \\
\text { Global Expansion } \\
\text { Strategy: Promotion and } \\
\text { Suppression } \\
\text { Modern Corporate Finance } \\
\text { Organization } \\
\text { Market Building } \\
\text { E-commerce }\end{array}$ & $\begin{array}{l}\text { The courses are closely } \\
\text { related to real situations } \\
\text { of companies. Students } \\
\text { can develop their } \\
\text { leadership skills through } \\
\text { simulation experiments. }\end{array}$ \\
\hline $\begin{array}{l}\text { London } \\
\text { Business School }\end{array}$ & & $\begin{array}{l}\text { Management Science } \\
\text { Accounting } \\
\text { Financial Analysis } \\
\text { Strategy } \\
\text { Organizational Behavior } \\
\text { Managerial Economics } \\
\text { Decision and Risk Analysis } \\
\text { Information Management } \\
\text { Marketing } \\
\text { Career Development Plan } \\
\text { Management Accounting }\end{array}$ & $\begin{array}{l}\text { More than } 70 \text { elective } \\
\text { curriculums are offered to } \\
\text { students for selection. }\end{array}$ & $\begin{array}{l}\text { 1. It concentrates on } \\
\text { international exchanges } \\
\text { with more than } 30 \text { first- } \\
\text { class universities in the } \\
\text { world in order to expand } \\
\text { the network. } \\
2 \text {. It encourages students } \\
\text { to analyze and solve } \\
\text { practical problems in } \\
\text { teams }\end{array}$ \\
\hline $\begin{array}{l}\text { Ivey Business } \\
\text { School }\end{array}$ & $\begin{array}{l}\text { Operation Management } \\
\text { Management Accounting } \\
\text { Project Management } \\
\text { Finance }\end{array}$ & & $\begin{array}{l}\text { Securities Investment } \\
\text { Advanced Consumer } \\
\text { Behavior } \\
\text { Global Supply Chain } \\
\text { Management } \\
\text { Enterprise Financial } \\
\text { Statement } \\
\text { Value Investing } \\
\text { Advanced } \\
\text { Management Product } \\
\text { Globalization Strategy }\end{array}$ & $\begin{array}{l}\text { 1. Students need to } \\
\text { complete } 9 \text { of } 24 \text { elective } \\
\text { courses. Each course } \\
\text { requires } 30 \text { hours. } \\
\text { 2, There are all required } \\
\text { curriculums during the } \\
\text { first year. In the second } \\
\text { year, the required } \\
\text { curriculum only } \\
\text { contains operation } \\
\text { management. }\end{array}$ \\
\hline
\end{tabular}




\section{CURRICULUM}

Different countries have different features of curriculum. Table 2 shows curriculum planning of different overseas business schools. In America, business schools aim to expose students to a wide range of knowledge so that students can possess good foundations and broad horizons. Most American business schools offer basic courses, nonspecialized courses and required courses. The number of basic courses and non-specialized courses is more than that of the required courses. As for Japanese business schools, they strive to arrange scientific, continuous, standardized and advanced courses in order to attach equal importance to theory and practical. Business schools in Britain, on the other hand, pay attention to foreign languages learning. They offer public courses between different specialties while professional courses are provided at the same time. Besides, all specialties have both core courses and elective courses. In addition, the provision of interdisciplinary or cross disciplinary courses has become another prominent feature in recent years. In short, overseas business schools concentrate on basic education in order to enhance students' basic skills and help them adapt to the ever-changing global business environment. Based on this, students can strengthen their understanding of professional courses.

\section{TEACHING METHODS}

When it comes to teaching methods, foreign business schools pay more attention to the case teaching, and place students in the actual business environment. Students can acquire practical knowledge through analyzing actual situation of various companies. They receive a lot of information everyday, through which their analysis and judgment competence will be improved. In Japanese business schools, the practical teaching has three main patterns, including exercises, internships and graduate studies. European and American business schools, on the other hand, conduct this through case teaching, group discussion, team activities, organizing professional associations' activities, encouraging students to participate in enterprise internships, etc. Foreign teaching methods generally emphasize practical teaching while the theoretical study is guided by teachers and learned by students themselves. There is an overview in Table 3.

TABLE III. OVER VIEW OF TEACHING METHOdS IN OVERSEAS BUSINESS SCHOOLS

\begin{tabular}{|c|c|}
\hline Business Schools & Teaching Methods \\
\hline Harvard Business School & $\begin{array}{l}\text { 1. Using case teaching methods to teach students how to make decisions and improve their } \\
\text { management level. } \\
\text { 2. Encouraging interdisciplinary research in order to investigate thinking and behaviour patterns } \\
\text { of managers. } \\
\text { 3. Inviting celebrities to participate in conferences, forums and lectures. } \\
\text { 4. The latest information on enterprise management across borders and cultures is supported by } \\
\text { several research centres around the world, including those in Asia Pacific, Latin America, } \\
\text { Europe, Japan, etc. }\end{array}$ \\
\hline $\begin{array}{l}\text { Wharton School of the University of } \\
\text { Pennsylvania }\end{array}$ & $\begin{array}{l}\text { 1. During the first year of study, students must participate in distinctive corporate advisory } \\
\text { activities that requires team participation. } \\
\text { 2. Students are given opportunities to spend one semester studying at business schools in the } \\
\text { other ten countries in order to gain international experiences. } \\
\text { 3. In addition to the classroom, students can participate in e-commerce clubs, conferences and } \\
\text { other organizations to develop leadership skills and team skills. } \\
\text { 4. Students will spend several weeks in foreign companies to investigate and understand the } \\
\text { operating environment and cultural backgrounds of those companies. }\end{array}$ \\
\hline Stanford Graduate School of Business & $\begin{array}{l}\text { 1. The teaching structure is flexible and diverse. It allows students to arrange their own studies. } \\
\text { 2. Courses are the combination of collective cooperation projects, lectures and case analyzes. } \\
30 \% \text { of the learning materials come from abroad. } \\
\text { 3. The number of students is relatively low in each class. Besides, teamwork is emphasized. }\end{array}$ \\
\hline London Business School & $\begin{array}{l}\text { 1. Students are from more than } 70 \text { countries using more than } 60 \text { different languages. } \\
\text { 2. Attaching importance to the international business language. } \\
\text { 3. More than } 30 \text { international exchange projects can be used for case studies and field } \\
\text { exchanges. Besides, they have practice bases in Silicon Valley. }\end{array}$ \\
\hline Ivey Business School & $\begin{array}{l}\text { 1. It mainly conducts case teaching methods and is the world's largest case producer except } \\
\text { Harvard Business school. } \\
\text { 2. It emphasizes on collective learning while going it alone is not encouraged. } \\
\text { 3. It mainly relies on the business learning centres to develop global teaching ideas. Meanwhile, } \\
\text { It assigns students to conduct intercollegiate exchanges with Asian and European business } \\
\text { schools. }\end{array}$ \\
\hline
\end{tabular}




\section{Cultivation System}

Overseas business schools have different methods of assessment on teaching. Each country has formed its own cultivation system over the long period.

\section{A. America}

American business schools' undergraduate education plays a connecting role between graduate education and senior high school education. They adopt the credit system which means each student will receive a certain number of credits after completing a course successfully. When students get enough credits, they can graduate.

\section{B. Germany}

German business schools only set regular term limits on registered learning time. After students fulfil that, they are allowed to attend the graduation exam. On the other hand, there is no clear regulation for the highest number of semesters. In this sense, German business schools do not have definite educational system.

\section{Japan}

There are three levels of higher education in Japanese business schools, that is, junior college education, undergraduate education and postgraduate education. But higher education is mainly based on undergraduate education. More importantly, it is the focus of business education in Japan, which adopts the 4-year educational system. After getting enough credits, students will receive the bachelor's degree in business.

\section{EVALUATION AND CONCLUSION}

To sum up, the development level of talent education in foreign business schools is relatively higher, which is presented in the following aspects.

\section{A. Teaching's Close Integration with Enterprises}

With the change of world economy, companies are facing new competition environment. In order to adapt to the everchanging world and requirements of companies, business schools are conducting educational reforms. The participation of companies in teaching management is increasing, so that teaching can be closely related to the real situation of companies. In response to this, many business schools start to offer courses in international business negotiations. Some are changing focus of teaching and research to adapt to this situation. For example, Wharton School of University of Pennsylvania is known for financial research. However, in order to educate managers how to face global competition, it begins to concentrate on management of multinational corporations. Fuqua School of Business pays more attention to the development of information technology, as over $75 \%$ of courses are using computers.

\section{B. Large Scale of Education}

Today, peace and development are still the themes in the context of the present era, and all countries are concentrating on economic development. As a requirement of that, the demand for business talents further increased. A qualitative leap can be seen both in enrolment scale and education scale of business schools. For example, in 1860s, there were approximately 50 thousand people who received the bachelor's degree in business. In the early 1880 s, this figure reached 200 thousand, accounting for $21.5 \%$ of all undergraduate students, and exceeded the number of students in other majors. In the late 1880 s, this figure increased to 250 thousand while the proportion rose to $24 \%$. For most freshmen in America, getting a business-related job is the most common and fashionable choice. As a leader of world business education, America contributes a lot to its development. As a result of that, many countries begin to follow the example of America. Thus, the scale of business education will be further increased.

\section{Close International Exchanges}

The coming integration of world economy and information age promote the internationalization of business education. Overseas business schools are taking measures to improve teaching standards and enhance international cooperation, such as encouraging cooperation in running schools, exchanging students, bringing in specialists, etc. For instance, NUS Business School has tried to hire famous overseas professors in order to make up for its weaknesses. Besides, it has also set up overseas recruitment office to attract top talents from European and American universities.

\section{ACKNOWLEDGMENT}

This paper benefits from Teaching Research Project of University of Jinan (J1615) - Comparison of Talent Training Models between Domestic and Overseas Business Schools and Reform Strategies for Chinese Business Schools. We deeply appreciate the valuable comments of the anonymous referees.

\section{REFERENCES}

[1] Zhang Yuli and Chen Zhongwei, "Comparison and Reference on Talents Training Level for Business Administration Program of Overseas Famous Business Schools," Management Review, vol. 15, pp. 56-62, April 2003.

[2] Wang Jingjing, Lan Yujie, and Du Jinging, "Comparison and Inspiration on the Training Models of MBA in World Famous Business Schools," Education \& Modernization, vol. 95, pp. 84-90, June 2010.

[3] Han Yuzhi, "Comparative Study on Undergraduate Training Models of Business Administration," Exploring Education Development, vol. 12, pp. 53-56, December 2004

[4] Zhao Shan, "Analysis and Reference on MBA Talents Training Models of American Business Schools," Contemporary Education Sciences, vol. 5, pp. 51-55, March 2014.

[5] Liu Xingguo, Lu Fangming, and Liang Jing, "Characteristics of German Higher Education and Its Enlightenment," Education Exploration, vol. 206, pp. 138-139, August 2008.

[6] Han Yuzhi, "Exploration on the Reform Orientation of the Training Models of Business Administration in China," Business Administration, vol. 11, pp. 81-82, November 2004. 